\title{
HUBUNGAN PENGETAHUAN DAN SIKAP DENGAN PERILAKU PENCEGAHAN COVID-19 PADA MASA ADAPTASI KEBIASAAN BARU
}

\author{
Nissa Noor Annashr ${ }^{1}$, Puji Laksmini ${ }^{2}$, Andy Muharry ${ }^{3}$, Teni Supriyani ${ }^{4}$, Rian Arie \\ Gustaman $^{5}$ \\ Program Studi Kesehatan Masyarakat, Universitas Siliwangi1,2,3,5 \\ Program Studi Kesehatan Masyarakat, STIKes Respati ${ }^{4}$ \\ annashr.nissa46@gmail.com
}

\begin{abstract}
In October 2020, West Java became the province with the third highest positive confirmed case of COVID-19 in Indonesia, with 33,147 cases with a death of 649. The purpose of this study was to analyze the relationship between knowledge and attitudes with COVID-19 prevention behavior during the adaptation period of new habits. This study was an analytic observational study with a cross sectional study design. The study was conducted in September 2020. The study population was people aged 12 years living in West Java Province. The sample in this study amounted to 2,502 people. The sample was people who are willing to fill out a questionnaire that is distributed online (google form) via whatsapp, instagram and facebook so that the sampling technique includes accidental sampling. The independent variables studied consisted of knowledge and attitudes, while the dependent variable was COVID-19 prevention behavior during (habit of keeping distance, washing hands with soap, using masks). The results of univariate analysis showed that more than half of the respondents had good knowledge (56.8\%) and positive attitudes (54.6\%). The majority of respondents had good COVID-19 prevention behavior (73.3\%). The results of the bivariate analysis showed that there was a significant relationship between knowledge and attitude variables with COVID-19 prevention behavior ( $p$ 0.05). The OR value for the knowledge variable is 1.933 (95\% CI: 1.616-2.312). Meanwhile, the OR value for the attitude variable is 3.067 (95\% CI: 2.523-3.729). This study proves that knowledge and attitudes are significantly related to COVID-19 prevention behavior.
\end{abstract}

Keywords : Knowledge, Attitude, Preventive Behavior, COVID-19, The Adaptation Period Of New Habits

ABSTRAK

Pada Bulan Oktober 2020, Jawa Barat menjadi provinsi dengan kasus terkonfirmasi positif COVID-19 ketiga tertinggi di Indonesia, yaitu sebanyak 33.147 kasus dengan jumlah kematian sebanyak 649 . Tujuan dari penelitian ini adalah untuk menganalisis hubungan pengetahuan dan sikap dengan perilaku pencegahan COVID-19 pada masa adaptasi kebiasaan baru. Penelitian ini termasuk penelitian observasional analitik dengan desain studi cross sectional. Penelitian dilakukan pada bulan September 2020. Populasi penelitian adalah penduduk berusia $\geq 12$ tahun yang tinggal di Provinsi Jawa Barat. Sampel dalam penelitian ini berjumlah 2.502 orang. Sampel merupakan orang-orang yang bersedia untuk mengisi kuesioner yang disebarkan secara online (google form) melalui whatsapp, instagram dan facebook sehingga teknik pengambilan sampel termasuk accidental sampling. Variabel independen yang diteliti terdiri dari pengetahuan dan sikap, sedangkan variabel dependen adalah perilaku pencegahan COVID-19 pada masa AKB (kebiasaan menjaga jarak, mencuci tangan dengan sabun, menggunakan masker). Hasil analisis univariat menunjukkan lebih dari sebagian responden memiliki pengetahuan yang baik $(56,8 \%)$ dan sikap yang positif $(54,6 \%)$. Mayoritas responden memiliki perilaku pencegahan COVID-19 yang baik (73,3\%). Hasil analisis bivariat menunjukkan terdapat hubungan yang signifikan antara variabel pengetahuan dan sikap dengan perilaku pencegahan COVID-19 $(\mathrm{p} \leq$ $0,05)$. Nilai OR untuk variabel pengetahuan sebesar 1,933 (95\% CI : 1,616-2,312). Sementara itu, nilai OR untuk variabel sikap sebesar 3,067 (95\% CI : 2,523-3,729). Penelitian ini membuktikan bahwa penegtahaun dan sikap berhubungan secara signifikan dengan perilaku pencegahan COVID-19.

Kata Kunci : Pengetahuan, Sikap, Perilaku Pencegahan, COVID-19, Masa Adaptasi Kebiasaan Baru 


\section{PENDAHULUAN}

World Health Organization (WHO)
resmi menetapkan
(Coronavirus Disease 2019) sebagai pandemi global sejak tanggal 11 Maret 2020. Penyakit ini tergolong ke dalam penyakit yang sangat menular (Wake, 2020). Hingga Oktober 2020, angka kejadian COVID-19 masih terus meningkat. Per 23 Oktober 2020, terdapat 41.605.144 kasus dengan 1.135.006 kematian terkonfirmasi secara global. Pada tanggal yang sama, di Indonesia terdapat 381.910 kasus yang terkonfirmasi positif dengan total kematian sebanyak 13.077. Jawa Barat menjadi provinsi dengan kasus ketiga tertinggi di Indonesia, yaitu sebanyak 33.147 terkonfirmasi positif dengan jumlah kematian sebanyak 649 (Kemenkes RI, 2020).

Pemerintah Indonesia menetapkan Keputusan Presiden Nomor 11 Tahun 2020 tentang Penetapan Kedaruratan Kesehatan Masyarakat (KKM) Corona Virus Disease 2019 (COVID-19). Dalam keputusan tersebut ditetapkan bahwa COVID-19 sebagai jenis penyakit yang menimbulkan KKM di Indonesia, wajib dilakukan upaya penanggulangan sesuai ketentuan peraturan perundang-undangan. Salah satu komponen penting dalam penanggulangan tanggap darurat kesehatan masyarakat dilakukan melalui Komunikasi Risiko dan Pemberdayaan Masyarakat (KRPM) (Kementrian Kesehatan Republik Indonesia, 2020).

Langkah-langkah yang dilakukan dalam respon KRPM bagi daerah dengan eskalasi kasus yang tinggi adalah menerapkan respon, mengedukasi individu maupun kelompok masyarakat dalam melakukan pencegahan dan pengendalian, serta menerapkan protokol kesehatan dengan konsepsi Adaptasi Kebiasaan Baru (AKB) (Kementrian Kesehatan Republik Indonesia, 2020). Konsepsi AKB ditempuh karena masyarakat tetap perlu produktif dalam berkegiatan dan melakukan aktivitas kehidupan sosial untuk memenuhi hajat hidupnya. Sementara itu, risiko dari hal tersebut tetap ada. Artinya, kegiatan dan aktivitas tersebut berpotensi dalam penularan COVID-19, sehingga perlu dilakukan mitigasi dampak pandemi COVID-19. Langkah mitigasi atau pengurangan risiko yang dipraktikan adalah melakukan perubahan pola hidup dengan tatanan Adaptasi Kebiasaan Baru (AKB). Kedisiplinan dalam menerapkan tatanan baru ini menjadi kunci dalam menekan penularan COVID-19.

Penerapan tatanan baru ini bukan hal yang mudah karena menyangkut aspek perilaku. Setiap individu mempunyai perilaku dan karakteristik yang berbeda. Faktor perilaku manusia berangkat dari tingkat kesehatan yang dipengaruhi dua faktor pokok, yaitu faktor perilaku dan faktor di luar perilaku (Fitriani, 2010). Hasil penelitian yang dilakukan oleh Moudy dan Syakurah di Indonesia menunjukkan bahwa terdapat hubungan antara pengetahuan dengan upaya pencegahan COVID-19 (Moudy \& Syakurah, 2020). Penelitian yang dilakukan oleh Ferdous, dkk di Bangladesh yang melibatkan penduduk berusia 12-64 tahun membuktikan bahwa sikap yang lebih positif menjadi faktor-faktor yang berhubungan dengan praktik pencegahan COVID-19 lebih sering (Ferdous et al., 2020).

Ada banyak faktor yang berhubungan dengan perilaku pencegahan COVID-19, yang tentu berpengaruh terhadap rantai penularan apalagi ketika diterapkannya tatanan Adaptasi Kebiasaan Baru (AKB). Oleh karena itu, peneliti tertarik untuk melihat perilaku pencegahan COVID-19 pada masa AKB di Provinsi Jawa Barat yang merupakan salah satu provinsi dengan kasus terkonfirmasi COVID-19 yang tinggi di Indonesia. Tujuan dari penelitian adalah untuk menganalisis hubungan pengetahuan dan sikap dengan perilaku pencegahan COVID-19. 


\section{METODE}

Penelitian ini sudah mendapatkan persetujuan etik dari Komisi Etik Penelitian Kesehatan Poltekkes Mataram dengan nomor surat : LB.01.03/1.1/3016/2020. Penelitian ini termasuk penelitian observasional analitik dengan desain studi cross sectional. Penelitian dilakukan pada bulan September 2020. Populasi penelitian adalah penduduk berusia $\geq 12$ tahun yang tinggal di Provinsi Jawa Barat. Sampel dalam penelitian ini berjumlah 2.502 orang. Sampel merupakan orang-orang yang bersedia untuk mengisi kuesioner yang disebarkan secara online (google form) melalui whatsapp, instagram dan facebook sehingga teknik pengambilan sampel termasuk accidental sampling.

Variabel independen terdiri dari pengetahuan dan sikap, sedangkan variabel dependen adalah perilaku pencegahan COVID-19 pada masa AKB (kebiasaan menjaga jarak, mencuci tangan dengan sabun, menggunakan masker). Variabel pengetahuan, sikap dan perilaku pencegahan COVID-19 diukur menggunakan kuesioner dalam bentuk google form. Berdasarkan skor pengetahuan, responden terbagi ke dalam 2 kategori yaitu responden termasuk ke dalam kelompok responden dengan tingkat pengetahuan yang kurang baik, jika skor pengetahuan mereka $<77,27$, sedangkan jika responden memiliki skor $\geq 77,27$, termasuk ke dalam kelompok responden dengan pengetahuan baik. Nilai 77,27 merupakan nilai median dari skor pengetahuan. Variabel sikap dibagi menjadi 2 kategori berdasarkan nilai median sehingga terbagi menjadi responden yang memiliki sikap positif jika responden memiliki skor $\geq 44$ dan sikap negatif jika responden memiliki skor $<44$.

Setelah data selesai dikumpulkan, kemudian dilakukan pengolahan data meliputi kegiatan editing, coding, processing dan cleaning. Selanjutnya data dianalisis secara univariat dan bivariat. Tujuan analisis univariat adalah untuk melihat distribusi frekuensi dari masingmasing variabel yang diteliti. Analisis bivariat menggunakan uji chi square.

\section{HASIL}

Tabel 1. Disribusi Frekuensi Variabel Pengetahuan dan Sikap

\begin{tabular}{llcc}
\hline \multicolumn{1}{c}{ Variabel } & Kategori & n & \% \\
\hline \multirow{2}{*}{ Pengetahuan } & Kurang baik & 1.080 & 43,2 \\
& Baik & 1.422 & 56,8 \\
\hline \multirow{2}{*}{ Sikap } & Negatif & 1.371 & 54,8 \\
& Positif & 1.131 & 45,2 \\
\hline
\end{tabular}

Berdasarkan hasil analisis univariat yang ditunjukkan oleh tabel 1, diketahui bahwa lebih dari sebagian responden memiliki pengetahuan yang baik $(56,8 \%)$ dan sikap yang positif $(54,6 \%)$.

Tabel 2. Disribusi Frekuensi Variabel Perilaku Pencegahan COVID-19

\begin{tabular}{llcc}
\hline \multicolumn{1}{c}{ Variabel } & Kategori & n & \% \\
\hline $\begin{array}{l}\text { Kebiasaan } \\
\text { mencuci tangan }\end{array}$ & $\begin{array}{l}\text { Tidak } \\
\text { pernah/jarang } \\
\text { Sering/selalu }\end{array}$ & 227 & 9,1 \\
& Tidak & 168 & 6,7 \\
\hline $\begin{array}{l}\text { Kebiasaan } \\
\text { menggunakan } \\
\text { masker }\end{array}$ & $\begin{array}{l}\text { pernah/jarang } \\
\text { Sering/selalu }\end{array}$ & 1.864 & 93,3 \\
\hline $\begin{array}{l}\text { Kebiasaan } \\
\text { menjaga jarak }\end{array}$ & $\begin{array}{l}\text { Tidak } \\
\text { pernah/jarang } \\
\text { Sering/selalu }\end{array}$ & 2.021 & 80,8 \\
\hline
\end{tabular}

Berdasarkan tabel 2, diketahui bahwa sebagian besar responden sudah memiliki kebiasaan mencuci tangan dengan frekuensi sering/selalu selama masa $\mathrm{AKB}$, dengan persentase sebesar 90,9\%, mayoritas responden sering/selalu menggunakan masker dengan persentase sebesar $93,3 \%$ dan $80,8 \%$ responden terbiasa menjaga jarak saat berada di luar rumah. Ketiga komponen perilaku tersebut kemudian dikonversi menjadi kategori perilaku pencegahan COVID-19 sebagaimana ditunjukkan oleh tabel 3 berikut ini.

Tabel 3. Kategori Perilaku Pencegahan COVID-19 


\begin{tabular}{clcc}
\hline Variabel & Kategori & n & \% \\
\hline Perilaku & $\begin{array}{l}\text { Kurang } \\
\text { baik }\end{array}$ & 668 & 26,7 \\
& Baik & 1.834 & 73,3 \\
\hline
\end{tabular}

Tabel 3 menunjukkan bahwa mayoritas responden memiliki perilaku pencegahan COVID-19 yang baik pada masa AKB $(73,3 \%)$.

Tabel 4. Hasil Analisis Bivariat antara Variabel Pengetahuan dan Sikap dengan Perilaku Pencegahan COVID-19

\begin{tabular}{|c|c|c|c|c|c|c|c|c|}
\hline \multirow{3}{*}{ Variabel } & \multicolumn{4}{|c|}{ Perilaku pencegahan } & \multicolumn{2}{|c|}{ Jumlah } & \multirow{3}{*}{$\begin{array}{c}\mathbf{p} \\
\text { value }\end{array}$} & \multirow{3}{*}{$\underset{(\mathbf{9 5 \%} \mathrm{CI})}{\text { OR }}$} \\
\hline & \multicolumn{2}{|c|}{ Kurang baik } & \multicolumn{2}{|c|}{ Baik } & \multirow[b]{2}{*}{$\mathbf{n}$} & \multirow[b]{2}{*}{$\%$} & & \\
\hline & $\mathbf{n}$ & $\%$ & $\mathbf{n}$ & $\%$ & & & & \\
\hline \multicolumn{9}{|l|}{ Pengetahuan } \\
\hline Kurang baik & 368 & 34,1 & 712 & 65,9 & 1.080 & 100 & 0,000 & \\
\hline Baik & 300 & 21,1 & 1.122 & 78,9 & 1.422 & 100 & & $\begin{array}{c}(1,616- \\
2,312)\end{array}$ \\
\hline \multicolumn{9}{|l|}{ Sikap } \\
\hline Negatif & 493 & 36,0 & 878 & 64,0 & 1.371 & 100 & 0,000 & $\begin{array}{c}3,067 \\
(2,523-\end{array}$ \\
\hline Positif & 175 & 15,5 & 956 & 84,5 & 1.131 & 100 & & $3,729)$ \\
\hline
\end{tabular}

Berdasarkan hasil analisis bivariat, diketahui bahwa terdapat hubungan yang signifikan antara variabel pengetahuan dan sikap dengan perilaku pencegahan COVID19 ( $\mathrm{p} \leq 0,05)$. Nilai OR untuk variabel pengetahuan sebesar 1,933. Hal tersebut mengindikasikan bahwa responden yang memiliki pengetahuan kurang baik memiliki kecenderungan 1,933 kali lebih besar untuk menerapkan perilaku pencegahan COVID-19 yang kurang baik, dibandingkan dengan responden yang memiliki pengetahuan baik. Sementara itu, nilai OR untuk variabel sikap sebesar 3,067 , artinya responden yang memiliki sikap negatif memiliki kecenderungan 3,067 kali lebih besar untuk menerapkan perilaku pencegahan COVID-19 yang kurang baik jika dibandingkan dengan responden yang memiliki sikap positif.

\section{PEMBAHASAN}

Dari 2.502 responden yang terlibat dalam penelitian ini, skor rata-rata untuk pengetahuan adalah 74,1952. Lebih dari sebagian responden memiliki pengetahuan yang baik dengan persentase sebesar $56,8 \%$. Berdasarkan analisis bivariat, diketahui bahwa variabel pengetahuan memiliki korelasi yang signifikan dengan perilaku pencegahan COVID-19 di masa AKB. Hasil ini sejalan dengan hasil penelitian yang dilakukan oleh Rahman dan Sathi. Dalam penelitiannya, mereka menemukan adanya korelasi positif antara skor pengetahuan COVID-19 dan skor praktik pencegahan $(\mathrm{r}=0,291, \mathrm{p}<0,01)$. Untuk 1 unit perubahan skor pengetahuan, terdapat peningkatan 1,73 kali kemungkinan responden untuk tinggal di rumah dan menggunakan masker (Rahman \& Sathi, 2020). Hal ini juga diperkuat dengan temuan dari penelitian Akalu yang menyebutkan bahwa responden dengan pengetahuan yang buruk lebih cenderung memiliki praktik yang buruk (Akalu et al., 2020).

Baik buruknya pengetahuan yang dimiliki seseorang dapat dipengaruhi oleh berbagai variabel. Penelitian yang dilakukan oleh Ferdous, dkk menunjukkan bahwa pengetahuan COVID-19 yang lebih akurat berkorelasi secara signfikan dengan variabel usia dan tempat tinggal (Ferdous et al., 2020). Almofada, dkk dalam penelitiannya juga mendukung temuan tersebut. Proporsi responden yang memiliki pengetahuan baik berbeda-beda antara wilayah atau lokasi tempat tinggal, dimana hampir setengah dari partisipan penelitian 
dari wilayah tengah $(49,8 \%)$ mengetahui tentang cara menghindari penyebaran COVID-19 dengan meninggalkan jarak (Almofada et al., 2020). Penelitian di Nigeria menunjukkan bahwa mayoritas responden dalam penelitiannya memiliki pengetahuan yang baik $(99,5 \%)$ tentang COVID-19 dan informasi mengenai COVID-19 mereka dapatkan terutama berasal dari internet/media sosial $(55,7 \%)$ dan televisi (27,5\%) (Reuben et al., 2020). Tingkat pendidikan juga memiliki kontribusi dalam mempengaruhi pengetahuan seseorang mengenai COVID19 sebagaimana dibuktikan dalam penelitian Akalu (Akalu et al., 2020).

Ada beberapa faktor yang dapat menjelaskan korelasi positif antara pengetahuan dan perilaku pencegahan COVID-19. Penelitian yang dilakukan oleh Yanti, dkk di Indonesia menunjukkan bahwa di antara responden yang memiliki pengetahuan yang baik juga menunjukkan sikap yang positif $(58,85 \%)$, dan perilaku yang baik dalam mengimplementasikan social disctancing (93,3\%). Responden yang memiliki sikap positif juga menunjukkan perilaku yang baik $(96,7 \%)$ (Yanti et al., 2020). Reuben, dkk di Nigeria menunjukkan kecenderungan yang sama bahwa mayoritas responden memiliki pengetahuan yang baik tentang COVID-19, memiliki sikap positif mengenai kepatuhan terhadap peraturan pemerintah, serta mayoritas dari responden juga mempraktikkan social distancing/isolasi diri, meningkatkan kebersihan diri dan menggunakan masker wajah (Reuben et al., 2020). Dengan demikian, dapat disimpulkan bahwa semakin baik pengetahuan, dapat meningkatkan kecenderungan seseorang untuk memiliki sikap yang positif serta berpengaruh juga terhadap penerapan perilaku yang lebih baik.

Hal ini kemungkinan disebabkan karena pengetahuan menjadi variabel utama yang dapat merubah sikap positif mengenai tindakan pencegahan COVID19. Tindakan pencegahan tersebut dilakukan oleh seseorang setelah mereka memiliki pengetahuan yang memadai mengenai cara penecgahan COVID-19 serta kesadaran yang baik. Dengan adanya tindakan pencegahan yang baik pada setiap individu maka akan terjadi pengurangan risiko untuk terinfeksi penyakit COVID-19 (Akalu et al., 2020) Menurut Notoatmodjo (2015), pengetahuan yang memadai mengenai bahaya dari suatu penyakit, akan menstimulus seseorang untuk menerapkan perilaku atau Tindakan pencegahan yang baik (Syadidurrahmah et al., 2020).

Penelitian ini menemukan lebih dari sebagian responden memiliki sikap yang positif $(54,6 \%)$. Hasil analisis bivariat membuktikan bahwa sikap berkorelasi secara signifikan dengan perilaku penecgahan COVID-19. Hasil penelitian ini didukung oleh penelitian di dalam maupun di luar negeri. Penelitian Yanti, dkk di Indonesia membuktikan responden yang memiliki sikap positif juga menunjukkan perilaku yang baik $(96,7 \%)$ (Yanti et al., 2020) Penelitian Peng, dkk di China menunjukkan terdapat korelasi positif antara sikap dan praktik $(r=0,319$, $\mathrm{p}<0,05)$.

Penelitian yang dilakukan oleh Ferdous, dkk juga menunjukkan hal serupa. Ferdous, dkk membuktikan bahwa sikap yang lebih positif menjadi faktor yang mempengaruhi praktik pencegahan COVID-19 lebih sering. Lebih lanjut Ferdous, dkk menjelaskan bahwa mayoritas responden setuju 'COVID-19 adalah penyakit berbahaya' serta beberapa faktor yang dapat mempengaruhi sikap seseorang menjadi lebih positif yaitu faktor sosiodemografi seperti usia lanjut, pendidikan tinggi, pekerjaan dan pendapatan bulanan keluarga yang tinggi (Ferdous et al., 2020). Penelitian Peng, dkk melaporkan bahwa sikap positif juga dipengaruhi oleh jenis kelamin, dimana perempuan menunjukkan tingkat sikap positif yang lebih tinggi secara signifikan daripada laki-laki ( $\mathrm{p}<0,05)$ (Peng et al., 2020). Tingkat pengetahuan juga memiliki kontribusi dalam mempengaruhi sikap 
seseorang, seperti dilaporkan dalam penelitian Yanti, dkk di antara responden yang memiliki pengetahuan yang baik, juga menunjukkan sikap yang positif, serta perilaku yang baik (Yanti et al., 2020).

Pengetahuan yang baik dan benar akan mempengaruhi sikap masyarakat menjadi lebih positif dan optimis. Van Nhu, dkk dalam penelitiannya melaporkan bahwa sikap optimis masyarakat Vietnam dalam menghadapi pandemi COVID-19 mungkin dapat dipengaruhi oleh adanya informasi terkini yang selalu diperbaharui di berbagai media massa yang ada di Vietnam sehingga masyarakat dapat mengikuti bagaimana perkembangan COVID-19. Hal ini juga diperkuat dengan kepercayaan masyarakat setelah melihat langsung bagaimana pemerintah Vietnam melakukan langkahlangkah pencegahan yang kuat sehingga jumlah kasus COVID-19 saat itu jauh lebih sedikit dibandingkan negara-negara lain di dunia (Van Nhu et al., 2020).

Penelitian Alzoubi di Jordan melaporkan responden sudah memiliki sikap yang positif dalam pencegahan COVID-19. Sikap positif tersebut termanifestasi dalam cara mereka melakukan berbagai upaya pencegahan yang tepat seperti mencuci tangan, menggunakan alkohol sebagai disinfektan, menghindari berjabat tangan, dan mengikuti tata cara pencegahan saat batuk dan bersin (Alzoubi et al., 2020). Hal ini sejalan dengan model perubahan perilaku, yang menjelaskan bahwa pengetahuan yang baik akan berkontribusi terhadap terbentuknya sikap positif, yang pada akhirnya akan meningkatkan praktik yang tepat.

\section{KESIMPULAN}

Penelitian ini membuktikan bahwa pengetahuan dan sikap memiliki hubungan yang signifikan dengan perilaku pencegahan COVID-19 pada masa AKB. Berdasarkan hasil penelitian, diharapkan pemerintah dalam hal ini Dinas Kesehatan bekerja sama dengan institusi pendiikan tinggi dapat meningkatkan upaya promosi kesehatan supaya masyarakat tetap mematuhi aturan pemerintah untuk menerapkan perilaku protokol kesehatan.

\section{UCAPAN TERIMAKASIH}

Peneliti mengucapkan terima kasih kepada seluruh civitas akademik Universitas Siliwangi yang sudah memberikan dukungan dalam pelaksanaan penelitian ini. Selain itu, kepada seluruh responden yang sudah bersedia menjadi sampel penelitian.

\section{DAFTAR PUSTAKA}

Akalu, Y., Ayelign, B., \& Molla, M. D. (2020). Knowledge, attitude and practice towards covid-19 among chronic disease patients at addis zemen hospital, Northwest Ethiopia. Infection and Drug Resistance, 13, 1949-1960. https://doi.org/10.2147/IDR.S258736

Almofada, S. K., Alherbisch, R. J., Almuhraj, N. A., Almeshary, B. N., Alrabiah, B., Al Saffan, A., \& Baseer, M. A. (2020). Knowledge, Attitudes, and Practices Toward COVID-19 in a Saudi Arabian Population: A Cross-Sectional Study. Cureus, 2(6). https://doi.org/10.7759/cureus.8905

Alzoubi, H., Alnawaiseh, N., Al-Mnayyis, A., Abu-Lubad, M., Aqel, A., \& AlShagahin, H. (2020). Covid-19 Knowledge, attitude and practice among medical and non-medical university students in Jordan. Journal of Pure and Applied Microbiology, 14(1), 17-24. https://doi.org/10.22207/JPAM.14.1.04

Ferdous, M. Z., Islam, M. S., Sikder, M. T., Mosaddek, A. S. M., Zegarra-Valdivia, J. A., \& Gozal, D. (2020). Knowledge, attitude, and practice regarding COVID19 outbreak in Bangladesh: An onlinebased cross-sectional study. PloS One, 15(10), $1-17$. https://doi.org/10.1371/journal.pone.023 9254

Fitriani, S. (2010). Promosi Kesehatan (1st ed.). Penerbit Graha Ilmu. 
Kemenkes RI. (2020). Situasi Terkini Perkembangan (COVID-19). In Kemenkes RI (Issue Oktober).

Kementrian Kesehatan Republik Indonesia. (2020). Keputusan Menteri Kesehatan RI No. HK.01.07/MENKES/413/2020 tentang Pedoman Pencegahan dan Pengendalian COVID-19 (pp. 31-34). https://covid19.kemkes.go.id/protokolcovid-19/kmk-no-hk-01-07-menkes413-2020-ttg-pedoman-pencegahandan-pengendalian-covid19\#.X6_ppmgzY2w

Moudy, J., \& Syakurah, R. A. (2020). Pengetahuan terkait usaha pencegahan Coronavirus Disease (COVID-19) di Indonesia. Higeia Journal of Public Health Research and Development, 4(3), 333-346. https://journal.unnes.ac.id/sju/index.php /higeia/article/view/37844/16595

Peng, Y., Pei, C., Zheng, Y., Wang, J., Zhang, K., Zheng, Z., \& Zhu, P. (2020). Knowledge, Attitude and Practice Associated with COVID-19 among University Students: a Cross-Sectional Survey in China. BMC Public Health, 20(1292), 1-8. https://doi.org/10.21203/rs.3.rs21185/v1

Rahman, A., \& Sathi, N. J. (2020). Knowledge , Attitude, and Preventive Practices toward COVID-19 among Bangladeshi Internet Users. 17(5). https://www.ejgm.co.uk/download/kno wledge-attitude-and-preventivepractices-toward-covid-19-amongbangladeshi-internet-users-8223.pdf

Reuben, R. C., Danladi, M. M. A., Saleh, D. A., \& Ejembi, P. E. (2020). Knowledge, Attitudes and Practices Towards COVID-19: An Epidemiological Survey in North-Central Nigeria. Journal of Community Health, 0123456789. https://doi.org/10.1007/s10900-02000881-1

Syadidurrahmah, F., Muntahaya, F., Islamiyah, S. Z., Fitriani, T. A., \& Nisa, H. (2020). Perilaku physical distancing mahasiswa UIN Syarif Hidayatullah Jakarta pada masa pandemi covid-19. Jurnal Perilaku Dan Promosi Kesehatan, 2(1), 29-37. https://www.google.com/url?sa=t\&rct=j $\& \mathrm{q}=\&$ esrc $=\mathrm{s} \&$ source $=\mathrm{w} e b \& \mathrm{~cd}=\& \mathrm{cad}=\mathrm{r}$ ja\&uact $=8 \&$ ved $=2$ ahUKEwiT9Lvu34Ht AhWDXSsKHdxiD1MQFjACegQIAhA C\&url=https\%3A\%2F\%2Fjournal.fkm. ui.ac.id\%2Fppk\%2Farticle\%2Fdownloa $\mathrm{d} \% 2 \mathrm{~F} 4004 \% 2 \mathrm{~F} 991 \& u s g=\mathrm{AOvVaw} 1 \mathrm{yF}$ PWCgvXpDB88ZS-94zWB

Van Nhu, H., Tuyet-Hanh, T. T., Van, N. T. A., Linh, T. N. Q., \& Tien, T. Q. (2020). Knowledge, Attitudes, and Practices of the Vietnamese as Key Factors in Controlling COVID-19. Journal of Community Health, 45(6), 1263-1269. https://doi.org/10.1007/s10900-02000919-4

Wake, A. D. (2020). <p>Knowledge, Attitude, Practice, and Associated Factors Regarding the Novel Coronavirus Disease $2019 \quad$ (COVID-19) Pandemic $</ \mathrm{p}>$. Infection and Drug Resistance, Volume 13, 3817-3832. https://doi.org/10.2147/idr.s275689

Yanti, B., Wahyudi, E., Wahiduddin, W., Novika, R. G. H., Arina, Y. M. D., Martani, N. S., \& Nawan, N. (2020). Community Knowledge, Attitudes, and Behavior Towards Social Distancing Policy As Prevention Transmission of Covid-19 in Indonesia. Jurnal Administrasi Kesehatan Indonesia, 8(2), 4. https://doi.org/10.20473/jaki.v8i2.2020. 4-14 